\title{
The tectonic evolution and new exploration results onhydrocarbon potential, cased study in the NE-Eastern part, Cuu Long basin,Vietnam continental shelf
}

- Tran Nhu Huy

- Tran Van Xuan

- Ngo Thuong San

- Tran Thi Mai Huong

Faculty of Geology and Petroleum Engineering, Ho Chi Minh city University of Technology, VNU-HCM

(Manuscript Received on August 10 ${ }^{\text {th }}, 2015$; Manuscript Revised on October $20^{\text {th }}$, 2015)

\begin{abstract}
New exploration results proved the presence of Tertiary sedimentary basins with hydrocarbon potential in the boundaries of Vietnam continental shelf. These basins were perhaps formed in the Early Oligocene on the Mesozoic basement of continental crust and were filled with mainly deltaic clastic sediments. Since very early Miocene these basins have linked together and extended wider. Sediments of marine and prograding delta facies accumulated and widespreaded on the whole continental shelf. At the Middle Miocene to present-day the opening of the Bien Dong Sea (Vietnam East Sea), the regional tectonic subsidence and the eustatic fluctuation had created sedimentary formations of open and deep marine facies with turbidite shale, platform carbonate including reef build-up. Andesite and

basalt extrusion occurred in form of dykes
\end{abstract} resulting from tectonic inversions in Late Oligocene, in the beginning of Middle Miocene, particularly in Late Miocene-Pliocene.

These Tertiary sedimentary basins are expected to have hydrocarbon potential and need to be investigated and explored adequately. The main risk is the drilling technology, the exploitation in the deep sea and high investment cost.

The recently exploration results in illustrated a better potential in Lower Oligocene reservoir in South East margin of Cuu Long basin and many new signs. These signs need to be highlight researched for predicting accumulation distribution in study area, in purpose of oil and gas exploration for next stages.

Keyword: Boundaries of continental shelf, prograding, retrograding, petroleum system, potential play, South East margin, lower Oligocene reservoir. 


\section{INTRODUCTION}

Boundary of Vietnam continental shelf exist the Tertiary sediment basins in which the oil and gas potential proved through exploration and production results.

The basins recognized generate from early Oligocene above continental foundation with Mesozoic age content deltaic clastic facies. At begin of Miocene the basins have been extent, correlated together with prominent marine and prograding delta facies covered throughout continental shelf.

Since Middle Miocene up to recent, associated with the extension of Eastern Sea, the subsidence of region and sea level variation raised the favorable conditions to develop open sea and deep water settings in which mostly content turbidite shale and terrace carbonate intermix with reef build-up. The andesite and basaltic extrusive may generate in dyke form and surface layers which related to tectonic reversed activities at the late Oligocene and early Middle Miocene and especially at the end of Miocene-Pliocene.

\section{THE TECTONIC EVOLUTION HISTORY}

The open sea and deep water regions of Vietnam continental shelf include areas of Bien Dongsea surrounding basins such as PhuKhanh basin, Eastern shelf of Nam Con Son basin, and TuChinh-Vung May basin group (figure 01). These basins been generated and developed in structural geology region complicatedly, the vestiges of micro MezozoicIndosinia plate which partly oceanismed during Bien Dong Sea widespreaded, happened mostly in Oligocene. These basins to be considered rift basins, which formed synthetic with rift and back-arc basins in South-East Asia (SEA), have similar development stages.
The convolution history of these basins include three main stages (fig 02, 03) [2]:

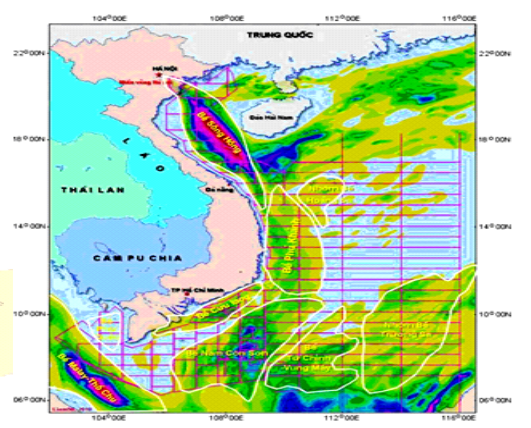

Figure 1. Distribution sketch of oil and gas basins in Vietnam continental shelf.

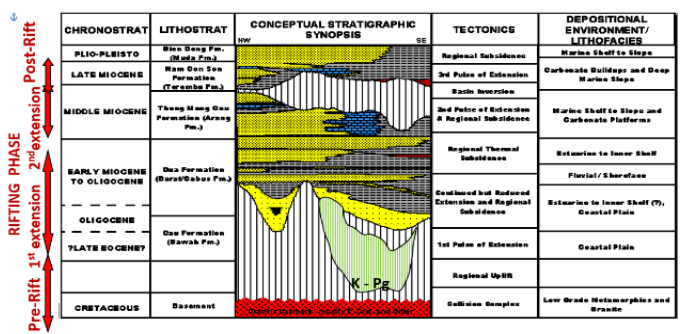

Figure 2. The evolution model of tectonic-facies Tertiary rift basin in boundaries of Vietnam continental shelf.

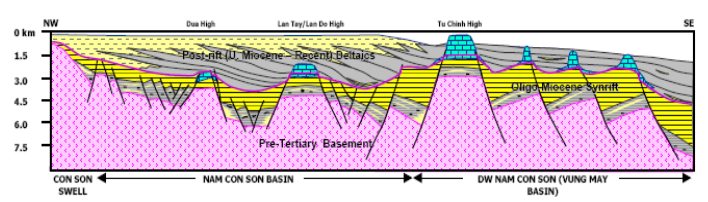

Figure 3. The cross section of generation and evolution model in boundaries of continental shelf sedimentary basins.

Pre rift stage Cretaceous-Paleogene (145-60 Ma) (figure04).

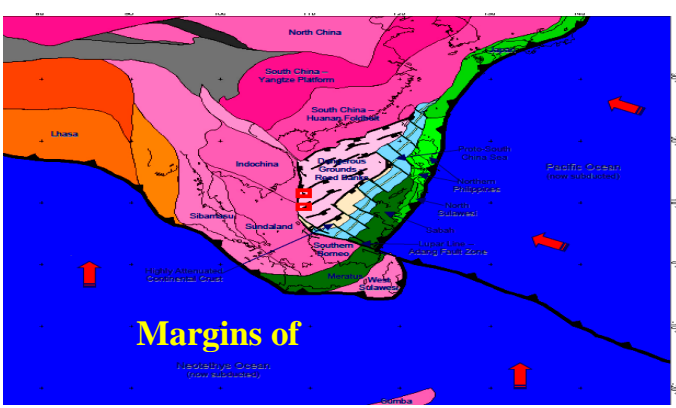

Figure 4. The tectonic evolution history of SEA, pre-rift stage (145-60 Ma) [1] 
Syn rift stage early Eocene-Miocene (55-15

Ma) (figures 05, 06).

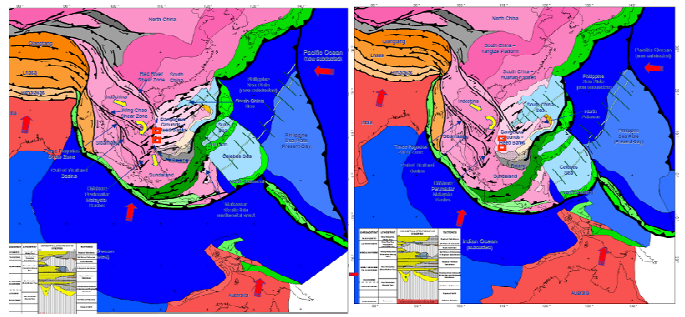

Figure 5. SEA tectonic convolution model of syn rift stage Early Eocene-Late Oligocene 43.5-23 Ma (left) and Oligocene-Early Miocene 23-21 Ma (right)
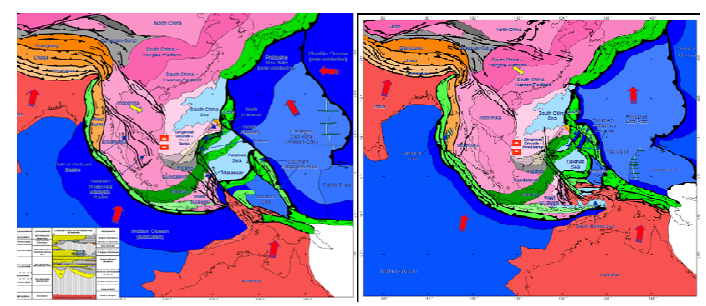

Figure 6. SEA tectonic evolution model of late rift stage Middle-Late Miocene 13-7.2 Ma (left) and post rift stage Late MiocenePliocene $\sim 6.8 \mathrm{Ma}$ (right).

Post rift stage Late Miocene -Pliocene Quarterly (after 7.2 Ma) (figure 07).

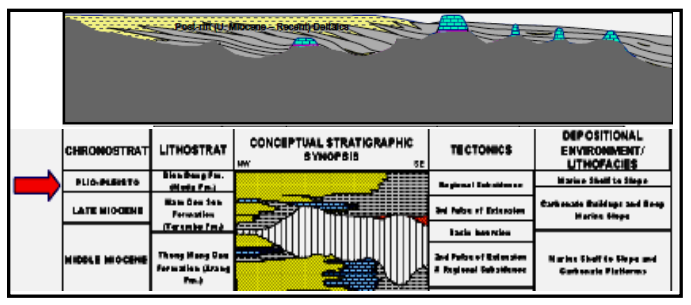

Figure 7. The evolution in the boundaries of continental shelf sedimentary basins in post rift stage Late Miocene-Pliocene.

\section{PETROLEUM SYSTEM IN BOUNDARIES OF CONTINENTAL SHELF SEDIMENTARY BASINS.}

In rift basins of continental shelf boundaries belong to deep water, fared edge have not anypetroleum exploration wells. The commercial hydrocarbon just discovery in shallow shelf with the depth $<500 \mathrm{~m}$ sea level, such as PhuKhanh basin, Nam Con Son basin in coral build up, clastic with ages of middle and lower Miocene. Based on seismic results and correlate with blocks which had the exploration well data could build up the petroleum system point of view for the offshoreregion (fig 08).

The Source Rock: The seismic interpretation results and tectonic evolution presented that the deep water and fared edge have the similar evolution history in the whole basin. The Paleogene and Miocene basins were buried by subsidiary thermo shrinkage in late Miocene and Pliocene-Pleistocene. The shale lacustrine sediment with abundant of organic matters and coal matter aged Oligocene as well shale of flooding plain are concerned of source rocks with have potential to generate hydrocarbon for deep water and fared edge regions at PhuKhanh, Nam Con Son and Tư Chính - Vũng Mây basins as well. The deep buries with fast subsidiary velocity of this source rock accelerate the maturation degree of organic materials and expelled the oil and gas out of the source rocks. The results of geochemistry modeling built up in PhuKhanh and Nam Con Son basins presented the organic materials those accumulated in syn-rift stage is falling in oil windows. The hydrocarbon expellee is continuously in Quarterly. The thick shale settings have $200-300 \mathrm{~m}$ thickness and distributed at $600-800 \mathrm{~m}$ deepare also determined have gas hydrate generating potential. 


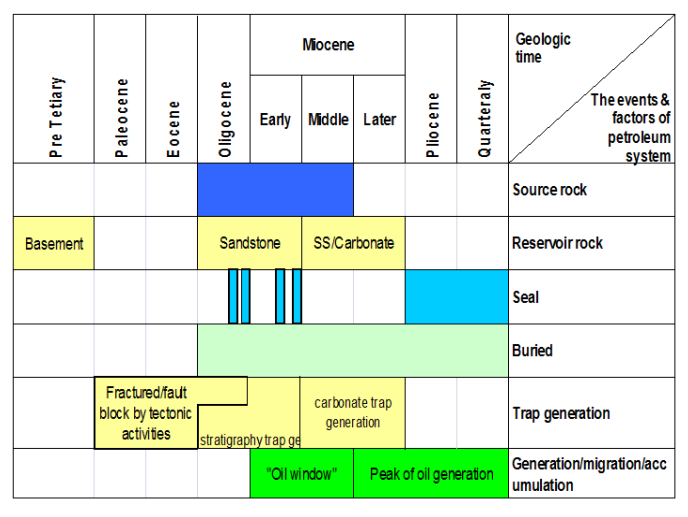

Figure 8. The sketch of petroleum system in deep water and fared edge sedimentary basins [2]

The Reservoir:Quite popularly with all Tertiary rift basins in Vietnam continental shelf, the reservoir rocksare pre-Tertiary fractured basement reservoirs, especially fractured Mesozoic granitoid blocks. The analysis results of basin sediment environment evolution performed the ability to generate the alluvial channel, alluvial fans and delta transmit sand, bars. The Oligocene and Miocene turbidite and carbonate reservoir in Middle-late Miocene coral built up formation are potential reservoirs as well.

The Seal: The cap rocks are regionally and locally in Oligocene-early Miocene shale formation and especially in thick deep water shale of Pliocene-Pleistocene. The faults also take the role as seal and to constrain the migration of oil and gas in structural traps.

The Trap: Most common are structural traps in such uplift block of basement, folds, usually associated with faults. These trap generated in inversed tectonic at the end of Oligocene -early Miocene (?) and Middle-later Miocene. Moreover, the coral build-up forms of aged Middle-early Miocene are important potential aspects as well. The stratigraphy and pinchout at the flank of folds are also need to concern discovery.
Point of view to petroleum play in boundaries of Vietnam continental shelf (figure 09)

At these Tertiary sedimentary basins in deepwater and marginal of Vietnam continental shelfperhaps existent the following hydrocarbon plays:

- Raised blockplay of pre-Tertiary fractured basement;

- Elevated-fault play of clastic sediments in syn-rift Oligocene- early Miocene;

- Build-up play of coral blocks, Middleearly Miocene carbonate form;

- Play turbidite Pliocene- early Pleistocene.

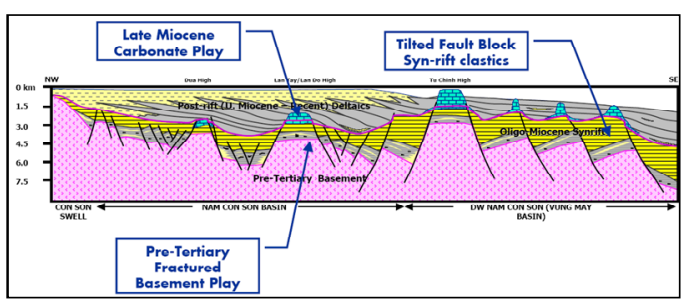

Figure 9. The distribution of hydrocarbon traps.

Play of pre-Tertiary elevated fractured basement block.(figure 10)

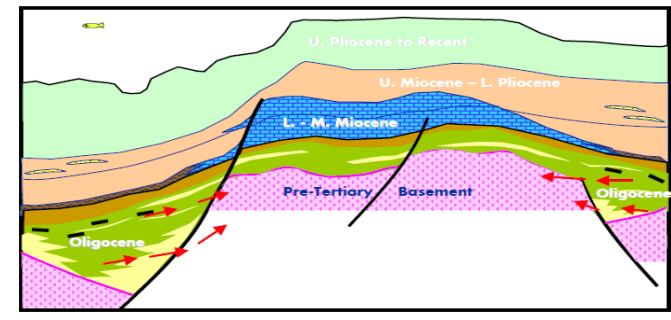

Figure 10. The point of view to petroleum play pre-Tertiary elevated fractured basement.

The Source rock: The Oligocene lacustrine thickness shale and shale coal generated in late rift covered on fractured basement.

The Reservoirs: Mostly Mesozoic(Jura, Creta) granitoid rocks and Mesozoic-Paleozoic metamorphism, moreover maybe Carbon-Permi fractured carbonate. 
The Seal: Lacustrine shale facies in Oligocene syn-rift, which generated the thickness cap throughout the region, the potential seal on pre-Tertiary elevated fractured basement.

The Trap: The buried raised blocks and elevated blocks with twisted and compressed along faults.

Built up carbonate and reef play (figure 11)

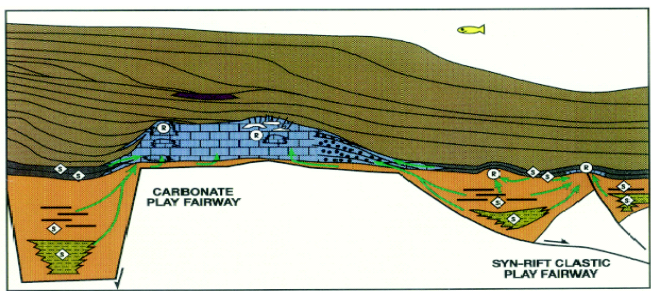

Figure 11. The point of view to lower-middle Miocene carbonate play.

The Source rocks: The abundant organic material shale, the Oligocene lacustrine coal shale, the shale of late Miocene seashore flood plain, the fared edge submarine fan;

The Reservoirs: Bio-carbonate, coral, dolomized carbonate aged of Middle-late Miocene.

The Seal: Shaly thickness cap in open sea, deep water, shale in rear of submarine fan of Pliocene-Pleistocene sedimentary settings.

The Trap:The built up carbonate with cap and wisp form, the reef, the dune of leaf-cuticle waxes aged Miocene, mainly middle-upper Miocene;

\section{Elevated-fault play (figure 12)}

The Source rocks: The Oligocene thickness coal-mud with lacustrine facies and Miocene marine shale abundant of organic materials.

The Reservoirs: The interbed sandstone in the Oligocene- early Miocene,syn-ryft clastic formation.
The Seal: The shale with restrict, locally distribution in Oligocene syn-ryft clastic formation, the moderate shale layers in early Miocene coastal sedimentary settings, the potential cap are also thickness marine shale of deep water settings in post-rift early MiocenePliocene. The faults not only take the role of migration path but also prevent the migration of oil and gas.

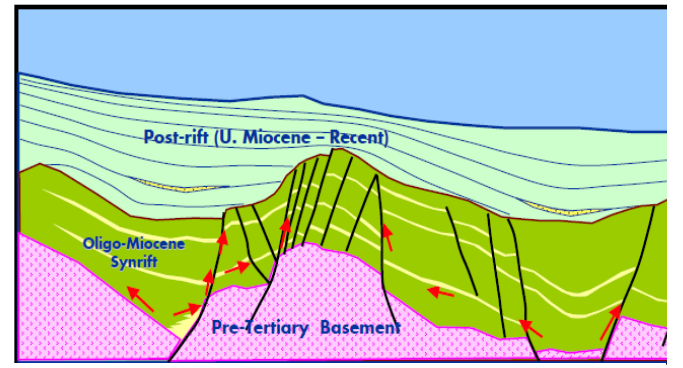

Figure 12. The point of view to elevatedfault block in rift generation Oligocene-Early Miocene play

The Trap: The elevated blocks divided by sealed faults.

\section{Turbiditeplay (Figure 13)}

The Source rocks: The shale stratum in which abundant organic materials interbed in to turbidite formation.

The Reservoirs: The sandy lens and thin layers interbed in to turbidite formation, sub marine fan and submarine channels.

The Seal: The shaly stratum with sub marine fan and deep water facies, interbed in to Pliocene and early Pleistocene turbidite formation.

The Trap: Normally are thin lens, multilayers, fold and stratigraphy traps in prograding wedges. 


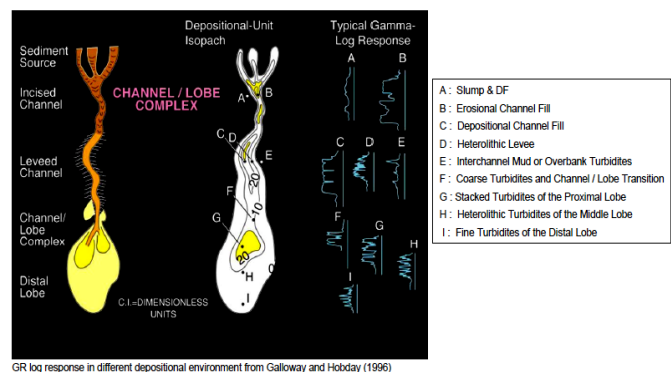

Figure 13. The distribution model of turbidite formation at sub marine fans [3]

\section{CASED STUDY IN THE NE-EASTERN PART, CUULONG BASIN [4]}

Recent wells of PVEP POC in Kinh Ngu Trang, Kinh Ngu Trang Nam area as well as Thang Long wells of Lam Son JOC also show that sand bodies in Oligocene $\mathrm{E}$ are the main reservoirs. From these wells, bituminous shale layers can be firmed as the seal of these sand bodies with thickness from 15 to 70mTVD (figure 14).

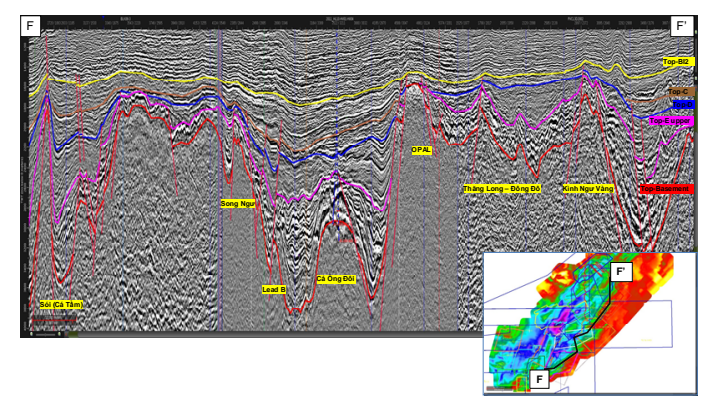

Figure 14. The seismic section shows the $\mathrm{E}$

Oligocene sequence distribution in NE-Eastern part of Cuu Long basin

\section{Stratigraphy and tectonic setting[4]}

Lower Tra Tan Formation - E/F (?) Sequence (Thickness: $0-1,500 \mathrm{~m}$ )

Generally, in Cuu Long basin, the "E/F?" Sequence underlies the organic rich dark yellowish brown shaly, claystone and is distinguished by the coarse grained and breccias/conglomerate of the sandstone with granitic fragments and above the weathered basement. It is generally thin or absent in most parts and is only present on the flank of the structures. Main characters of $\log$ curves of $\mathrm{E}$ sequence are relatively high density and resistivity, while DT is low.

This sequence is determined to be both excellent source and good reservoir. Depositional environment was alluvial-fluvial lacustrine conditions.

By the Late Oligocene time, the sediment source was more distal resulting in predominantly interbedded mudstones and sandstones being deposited in an environment varying from fluvial in South-West to more lacustrine in North-East of the basin. Very thick deposits of lacustrine shales filled the deep grabens in the Central and Northeast of the basin and draped over the basin horsts, setting up the hydrocarbons traps seen today. From late Early to early Late Oligocene time due to the opening of the East of Vietnam Sea, the faulting in the Cuu Long basin was reactivated and was associated with intensive volcanic activity throughout the basin. This reactivated faulting caused tilting and erosion of the previously deposited sediments (E and D sequences). At the end of Oligocene time the Northern basin was compressed resulting in the inversion of Oligocene section (fig. 15)

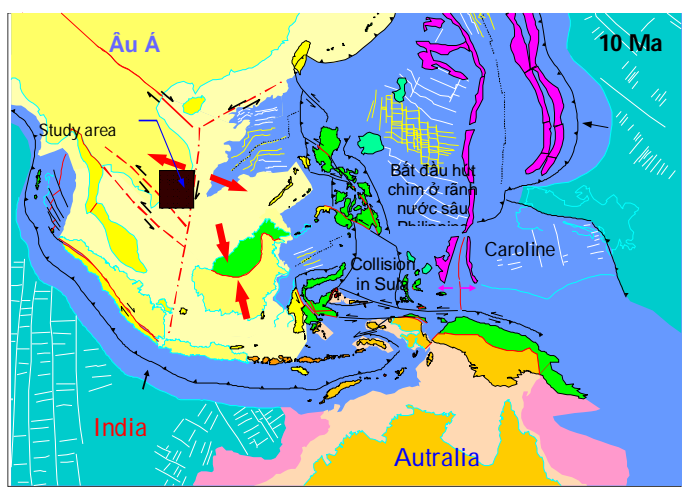

Figure 15. The Southeast Asia tectonic model at 10Ma (after Robert Hall, 2004 revised) 
The South-Eastern Cuu Long depression encompasses block 09.2 and 09.3. The main structural features of this depression comprise NE-SW, E-W and NW-SE trending faults.

\section{Petroleum system [4]}

\section{The Source Rock:}

In the Southeastern flank, in KNT area, Bitumen shale had been encountered in E lower section. This shale has thickness variety from 15 to $60 \mathrm{~m}$, it was deposited in deep lacustrine/lake condition (Fig.2.10). Geochemistry analysis for Bitum exhibit good to excellent organic richness (TOC 11\%) and show very good to excellent hydrocarbon generation potential $(\mathrm{S} 2 \sim 63 \mathrm{Kg} / \mathrm{T})$ (figure 16).

\section{The Seal:}

The regional transgressive shale (BH shale) at the most upper part of BI sequence is also known as an effective seal in the Cuu Long basin.

\section{The Reservoirs:}

Similar to Bach Ho North - East; Su Tu Nau; Diamond fields, in the study area the preserve porosity is moderately good, effective porosity in E sequence varies from 11 to $15 \%$, up to $18 \%$ at some wells. Base on the core and petrophysical analysis results the relation of porosity versus depth was conducted as figure 17.

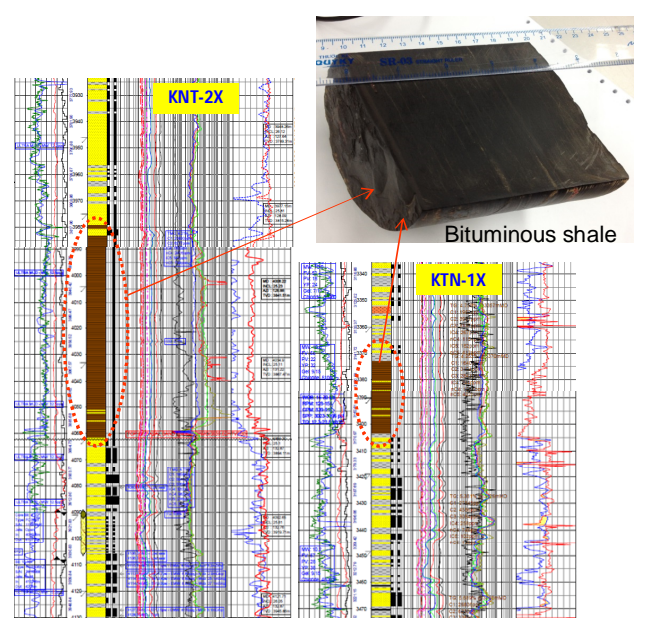

Figure 16. Bituminous shale encountered in KNT wells (right) and COD wells (left)

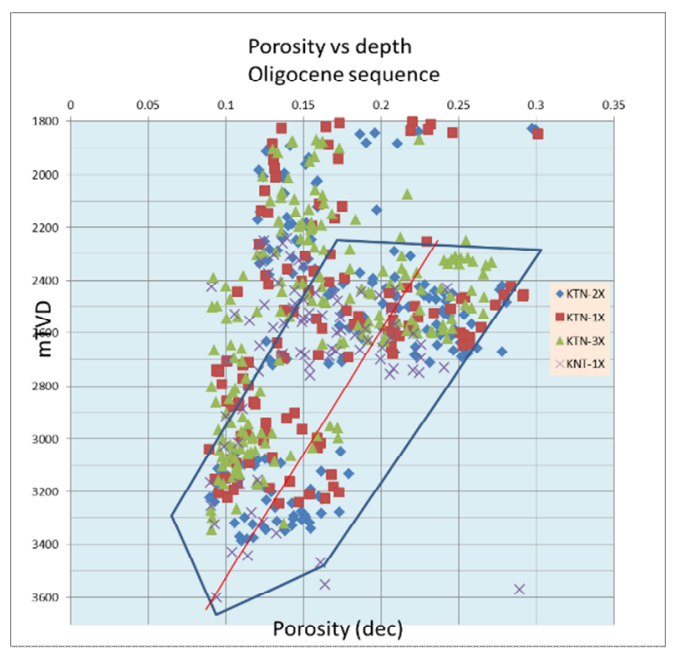

Figure 17. The porosity decreasing versus depth Oligocene sequence

The porosity decreasing versus depth chart (Figure 18) indicate the porosity of E sequence still well until penetrate at depth around 3,900 vertical meter. The effective porosity was preserved around 10 percent at depth 4,000 mTVD. 


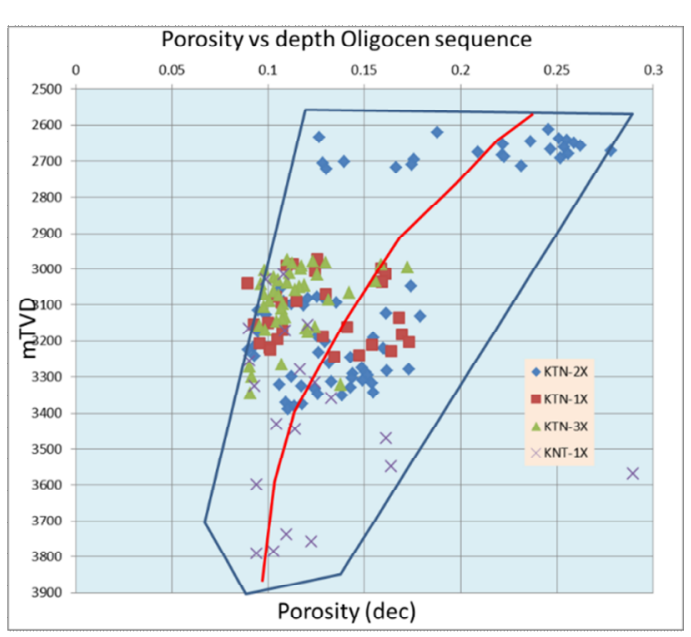

Figure 18. The porosity decreasing versus depth - E sequence

Equalize of porosity with permeability supported to fair quality of permeability, in the study area, the permeability could up to hundreds $\mathrm{mD} / \mathrm{cP}$ at some wells as figure 19.

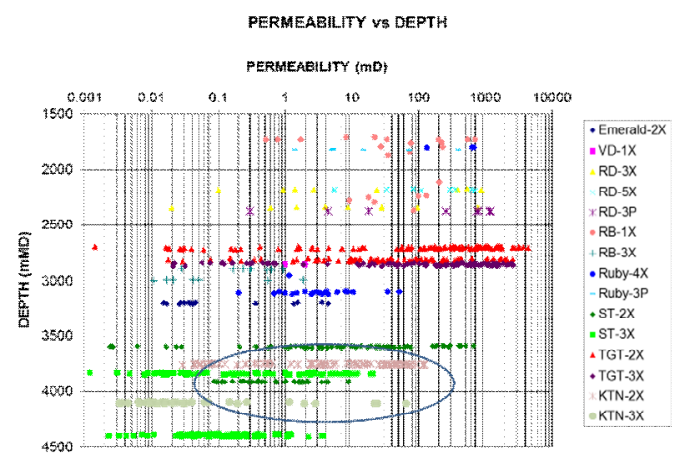

Figure 19. The permeability versus depth relation chart- Oligocene sequence

Exploration in 2005 - 2014 illustrated a better potential in Lower Oligocene reservoir in South East margin of Cuu Long basin and many new signs. These new signs need to be highlight researched for predicting accumulation distribution in study area, in purpose of oil and gas exploration for the next steps.

\section{CONCLUSIONS AND \\ RECOMMENDATION}

The survey results in margins of Vietnam continental shelf indicated, from geologic structure point of view, they are suture zone to deep sea area of PhuKhanh, Nam Con Son basins and develop the TuChinh-Vung May basin group. These basins were formed in the Late Eocene-Early Oligocene on the Mesozoic basement of continental crust and were filled with mainly clastic lacustrine, deltaic intermix with coastal sediments. Since Miocene, these basins have become extent and linked together with apparently sediments of marine and prograding delta facies accumulated and widespreaded on the whole continental shelf. At the Middle Miocene to present-day with the opening of the Bien Dong Sea, the regional tectonic subsidence and the eustatic fluctuation had created sedimentary formations of open and deep marine facies with turbidite shale, stacked sandstone. The rapid rate of deposition in the early Miocene-Pliocene accelerated the mature range of organic materials and the hydrocarbon expulsion at the beginning of early Miocene to the present-day. The organic material range is determined at the principle zone of oil and gas generation.

The oil and gas potential plays determined here after: (1) Raised block play of pre-Tertiary fractured basement; (2) Elevated-fault play of clastic sediments in syn-rift Oligocene- early Miocene; (3) Build-up play of Middle-early Miocene coral block, reef; (4)Play Plioceneearly Pleistoceneturbidite.

In addition with the conventional hydrocarbon resources, the unconventional hydrocarbon resources such as gas hydrate are also the potential aspect and needed to concern for research.

The main risk is the drilling and exploitation technology in the deep sea, high expenditure and investment cost. 
These Tertiary sedimentary basins in deepwater and marginal of Vietnam continental shelf are expected to have hydrocarbon potential and need to be investigated and explored.

Eocene - Oligocene reservoirs in Southeast margin Cuu Long basin preserved porosity permeability characteristics and probably got oil and gas industry flow in varied sedimentary facies. They distribute in a large area in the NEEastern part, Cuulong basin.

Acknowledgement: "This research is funded by Ho Chi Minh City University of Technology under grant number:TNCS - 2015

-

\section{Tiến hóa kiến tạo và một số kết quả thăm dò mới về tiềm năng dầu khí, lấy ví dụ khu vực Đông-Đông Bắc, bể Cửu Long, thềm lục địa Việt Nam}

- Trần Như Huy

- Trần Văn Xuân

- Ngô Thường San

- Trần Thị Mai Hương

Khoa Kỹ thuật Địa chất \& Dầu khí, Trường Đại học Bách Khoa, ĐHQG-HCM

\section{TÓM TẮT}

Nhũng kết quả thăm dò, tìm kiếm dầu khí bổ sung thời gian gần đây đã khẳng định ở rìa thềm lục địa Việt nam tồn tại các bể trầm tích Đệ tam có tiềm năng về dầu khí. Các bể này được thùa nhận hình thành vào đầu Oligocen trên móng lục địa có tuổi Mesozoi với các trầm tích luc nguyên tương châu thổ. Vào đầu Miocen các bể được mở rộng, liên kết với tướng biển và châu thổ lấn tiến (prograding delta) phủ rộng khắp thềm lục địa. Từ Miocen trung đến hiện nay với sự mở rộng của Biển Đông, sụ sụt lún khu vục và dao động mưc nước đại dưong đã tạo sự phát triển các trầm tích biển sâu với các tuoóng sét turbidit, xenvới các thể san hô ám tiêu.
Các thể andesit, basalt có thể được hình thành ở dạng các dyke vàl ớpphủ liên quan đến các hoạt động nghịch đảo kiến tạo vào cuối Oligocen, đầu Miocen giũ̃a và đặc biệt vào cuối MiocenPliocen.

Các bể trầm tích Đệ tam này được đánh giá có tiềm năng dầu khí và cần được nghiên cứu và tìm kiếm thăm dò. Rủiro lớn nhất là công nghệ khoan và khai thác vùng biển sâu và vốn đầu tu lớn.

Trong nhũng diều kiện thuận lợi, sụ có mặt của nhân tố ảnh hương tích cực đến việc bảo tồn tính rông thấm của tập E Oligocen chính là tập sét biển tiến phân bố tại phần nóc của của 
nhịp BI, đóng vai trò là tấm khiên để giảm thiểu tác động của áp suất địa tĩnh đã làm cho thành hệ tuổi Eocene - Oligocene vùng rìa Đông Nam bể Cưu Long có độ rỗng-thấm được bảo tồn tốt và có khả năng cho dòng dầu công nghiệp trong nhiều loại đá chứa khác nhau. Chúng phân bố trong phạm vi rộng lớn của vùng Đông-Đông Bắc, bể Cửu Long.
Kết quả thăm dò mói đã chứng tỏ trong thành hệ Oligocen hạ có tiềm năng dầu khi đáng quan tâm tại khu vực rìa Đông Nam bể Cưu Long cùng rất nhiều dấu hiệu móit. Các biểu hiện mới này cần được chú trọng trong công tác dụ báo khả năng có mặt các tích tu dầu khí tại khu vực nghiên cứu phục vu các buớc tiếp theo của công tác thăm dò dầu khí.

Tù Khóa: rìa thềm luc địa, tuớng biển tiến, tướng biển thoái, hệ thống dầu khí, play tiềm năng, rìa Đông Nam, tầng chứa trong Oligocen hạ.

\section{REFERENCES}

[1]. MetcalfeIan, 2011, Tectonic framework and Phanerozoic evolution of Sundaland, Gondwana Research 19 (2011) 3-21;

[2]. Ngo Thuong San et al, 2007, Vietnam geology and petroleum resources, Monograph of PetroVietnam;

[3]. Galloway, W. E., and Hobday, D. K., 1996, Terrigenous clastic depositional systems, Heidelberg, Springer-Verlag.
[4]. Tran Van Xuan et al, Final report on project "Study of Depositional environment of E Oligocene sedimentary in Cuu Long basin and prediction of $\mathrm{E}$ sand distribution in PVEP POC's area", 2014. 